\title{
Library cuts bring tremors to geologists
}

[WASHINGTON] The US Geological Survey (USGS) is reassessing the role of its library, which is increasingly being used as a national information resource, following widespread criticism of a threatened cut to the library's acquisitions budget.

At the end of March, P. Patrick Leahy, the survey's chief geologist, announced to survey employees that, for fiscal year 1997 (starting on 1 October), spending on periodicals would have to be reduced to about $\$ 422,000$ - little more than half the amount $(\$ 815,000)$ required to continue the 2,238 subscriptions currently held by the library. (The book budget would be reduced by the same proportion, from $\$ 150,000$ to $\$ 78,000$.)

But last Thursday (10 April), Edward C. Roy Jr, president of the American Geological Institute (AGI) - which represents 30 member societies in the Earth sciences - capped a week of protest from both inside and outside the survey by sending a letter to the survey's director, Gordon Eaton, expressing "strong opposition" to the deep funding cuts.

Scientists at the Geologic Division which employs most of USGS's research scientists and provides more than threequarters of the library's funding - have been angered by the scale of the budget reduction, and by the fact that they were given only a week to suggest which journal subscriptions should be retained. A letter to Leahy from 55 scientists at the survey's headquarters in Reston, Virginia, expressed "horror and disbelief" at "this self-destructive decision".

Opposition to the proposed cuts from outside the survey has been led by Earth science librarians in universities, who view the USGS library as an invaluable information resource, especially as a source of foreign and other 'obscure' publications.

Having been forced to cancel subscriptions in response to their own budgetary pressures, librarians elsewhere in the country have come to rely on interlibrary loans from the USGS library. Dennis Trombatore, of the Walter Geology Library at the University of Texas at Austin, described the library holdings as "the jewel in [our] crown... the place of last resort for unusual materials", and "the best Earth science library in the world".

Another cause for alarm is that the Reston branch of the USGS library serves as the most important single resource for the GeoRef bibliographic database, and its printed counterpart, the Bibliography and Index of Geology. This database, produced by the AGI in Alexandria, Virginia, contains more than two million references to all types of Earth science information, including maps and theses as well as journal articles and books. It extends back to 1785 for North American geology, and to 1933 for the rest of the world.

John Mulvihill, GeoRef director at the
AGI, explains that the institute cannot afford to subscribe to all of the 4,000 or so publications currently indexed in GeoRef. Although the database receives bibliographic information from the journals themselves, it uses the Reston library to verify this information, and to acquire more detailed information for indexing.

In his letter to Eaton, Roy says GeoRef is already "scrambling to compensate for the subscriptions lost from earlier cuts [to the Reston library]" - 1,667 subscriptions have been cancelled since 1986. Charlotte Derksen at Stanford, who is on the GeoRef advisory committee, considers the Reston collections to be "the backbone and the flesh" of GeoRef, and suggests that the result of the proposed cuts "could well be [its] demise".

According to Barbara Ryan, USGS associate director for operations, the decision to cut the library budget so dramatically reflected disagreements between the different divisions of the survey. The library is part of the Geologic Division, but, with other divisions having to produce money for the library, "it's been a contentious issue for some time".

Last Friday (11 April), the library budget came up for discussion by the survey's policy council, whose members include the director, associate directors and heads of the USGS divisions. After the meeting, Ryan said that the reaction to the proposed cuts, and in particular the fact that the library was an important resource for users outside the survey, had prompted the policy council to reconsider the role of the library and how it

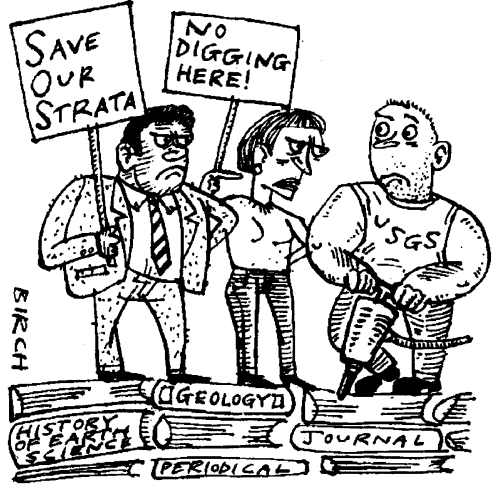

should be funded.

"Is it a library that just supports our research? Or a world-class collection that needs to be managed as such?" She said these questions were being put to the Library Board of Governors, a newly appointed body that met for the first time last month.

The board of governors was not consulted about the proposed cuts, according to its chair, Beth Duff. "The paperwork was in the mill at the time we met." The board is expected to report on its deliberations this autumn.

Meanwhile, there is the question of this year's budget. Ryan suggested there might be some flexibility - "we may take [the total for books and periodicals] up to $\$ 700,000 "$ but said that finding the extra money would be the responsibility of the Geologic Division. In the longer term, Ryan suspects that moving the library out of the Geologic Division, into the survey-wide Office of Program Support, will save it from becoming an object of interdivisional warfare. LauraGarwin

\section{Medical centre repays 'overbilled' $\$ \mathbf{1 5 . 5 m}$}

[WASHINGTON] New York University (NYU) Medical Center agreed last week to repay to the federal government $\$ 15.5$ million in connection with alleged overbilling of indirect research costs. A government spokesman said that four other universities are being investigated about similar allegations, but he refused to name them.

The NYU sum is the largest ever repaid to the government, and the House of Representatives Commerce committee, which has jurisdiction over indirect costs, is in contact with the Department of Health and Human Services and is "reviewing the situation". It was this committee, now chaired by Thomas Bliley (Republican, Virginia), which, under John Dingell (Democrat, Michigan), conducted widely publicized hearings on Stanford University's overbilling of indirect costs in the 1980s.

The NYU Medical Center's agreement to pay follows a three-year investigation by federal officials. The government concluded that the university had provided a "false, inaccurate and incomplete picture" of its research overhead costs in 1982 and 1993. For example, it said, the university billed food for medical school commencement ceremonies as research overhead costs.

The medical centre said it agreed to the settlement only in order to avoid a lengthy legal battle. "We clearly made some accounting and administrative mistakes," it said in a statement. But these were "inadvertent", and it continued to disagree with any characterization that "might suggest intentional misconduct".

Mary Jo White, the US Attorney for the Southern District of New York, said: "They intentionally submitted false claims in order to receive more money than they were entitled to." Cornelius J. Pings, president of the Association of American Universities, urged that the case "not be seen as evidence of a need for destabilizing a system that, on the whole, works well". 